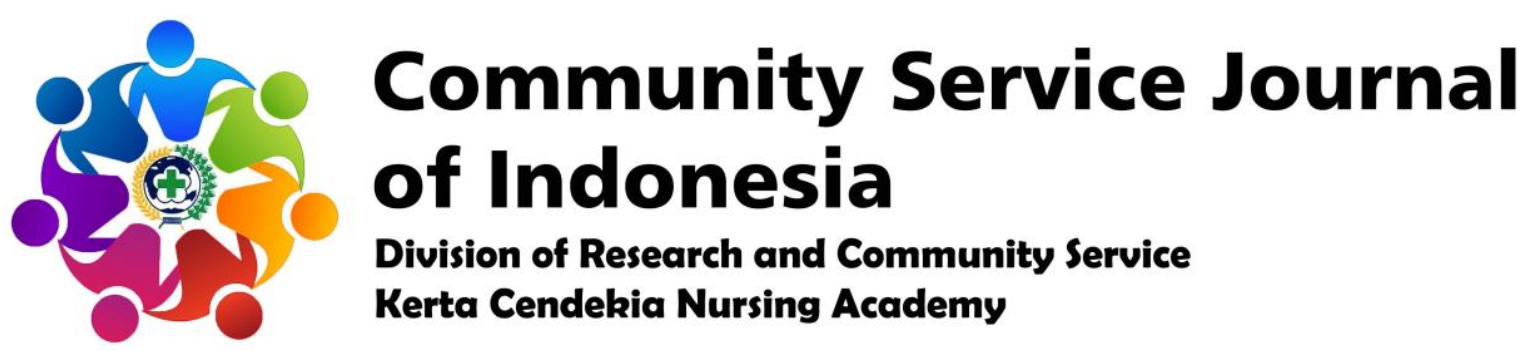

https://ejournal-kertacendekia.id/index.php/csji/index

Community Service Journal of Indonesia 2 (1) (2020): 10-13

Doi: https://doi.org/10.36720/csji.v2i1.143

\title{
INCREASING YOUTH KNOWLEDGE IN HANDLING MENSTRUAL PAIN IN STUDENTS OF THE ISLAMIC JUNIOR HIGH SCHOOL OF AL-MU'AWANAH, MINGGIR, SIDOARJO
}

\author{
Agus Sulistyowati ${ }^{1}$, Edgina Fidela Kusuma ${ }^{2}$, Ria Dinia ${ }^{2}$, Lela Anggarini ${ }^{2}$, Junaidah \\ Anugraheni ${ }^{2}$, Elisabeth Febi Fuankali ${ }^{2}$, Puji Yudha Raka Siwi ${ }^{2}$
}

${ }^{1}$ Lecturer of Kerta Cendekia Nursing Academy, Sidoarjo
${ }^{2}$ Students of Kerta Cendekia Nursing Academy, Sidoarjo

\begin{abstract}
Health promotion activities about the first aids during menstrual pain in the Islamic Junior High School of AlMu'awanah, Minggir, Sidoarjo is one form of community service in the form of counseling aimed at increasing children's knowledge about how the first treatment during menstrual pain which is an event of blood loss from the womb of a woman when she reaches baligh. The implementation of these activities on November 13, 2019 took place at the Islamic Junior High School of Al-Mu'awanah, Minggir, Sidoarjo. The target is all of the students of the Islamic Junior High School of Al-Mu'awanah, Minggir, Sidoarjo. Before the activity is carried out, there is a process of compiling the activity for approximately 2 weeks before the activity is carried out, starting from determining the theme of counseling to submitting licensing to the parties concerned. As a form of evaluation, the activity was attended by 26 students of VII grade of the Islamic Junior High School of Al-Mu'awanah, Minggir, Sidoarjo, participants took part in the activity happily and looked very enthusiastic, health promotion activities could run on time and smoothly.
\end{abstract}

Keywords: Youth knowledge, menstrual pain, health promotion of first aids.

(C) 2020 The Authors. Community Service Journal of Indonesia Published by Community Service and Research of Kerta Cendekia Nursing Academy - Kerta Cendekia Nursing Academy

This is an Open Access Article distributed under the terms of the Creative Commons Attribution 4.0 International License which permits unrestricted non-commercial use, distribution, and reproduction in any medium, provided the original work is properly cited.

E-ISSN

2684-7884

\section{INTRODUCTION}

Menstruation is the release of the inner layer (endometrium) accompanied by bleeding, recurring every month periodically, except during pregnancy. While the menstrual cycle is the time from 
the first day of menstruation until the arrival of the next period. Cases of menstrual pain (dysmenorrhea) usually occur in adolescents. Lack of knowledge and information possessed by most women about menstrual cycles, pre-menstrual syndrome, and menstrual disorders during reproduction, the authors are interested in discussing the problems that are often experienced by each of these women.

\section{OBJECTIVES}

\section{General Purpose}

After counseling, all students of Class VII of the Islamic Junior High School of Al-Mu'awanah, Minggir, Sidoarjo are expected to be able to understand how to handle the menstrual pain.

\section{Special Purpose}

After counseling, all representatives of students of Class VII of the Islamic Junior High School of Al-Mu'awanah, Minggir, Sidoarjo are expected to be able to:

1. Mention the meaning of menstrual condition.

2. Mention the process of menstruation.

3. Mention the causes of menstrual pain.

4. Mention the first aid when menstrual pain.

5. Mention how to treat vital areas during menstruation.

\section{PLAN OF ACTION}

\section{Strategy Plan}

The strategy plan implemented, including:

1. Coordinate with the principal of the Islamic Junior High School of AlMu'awanah, Minggir, Sidoarjo to request permission to carry out health education as a nursing program and to help provide useful knowledge for students of the Islamic Junior High
School of Al-Mu'awanah, Minggir, Sidoarjo.

2. Establish a time contract with students of the Islamic Junior High School of AlMu'awanah, Minggir, Sidoarjo.

3. Providing health education about how to handle menstrual pain in the Islamic Junior High School of Al-Mu'awanah, Minggir, Sidoarjo.

\section{Implementation}

Actions taken in the implementation of these activities, including:

1. Contacting the principal of the Islamic Junior High School of Al-Mu'awanah, Minggir, Sidoarjo to ask permission to carry out these activities and gather the students of the Senior High School of Antartika, Buduran, Sidoarjo.

2. Prepared the place and media for health promotion.

3. Carried out of the material of handling menstrual pain to the all representatives of students of Class VII of the Islamic Junior High School of Al-Mu'awanah, Minggir, Sidoarjo.

\section{Setting}

This activity was carried out at the Islamic Junior High School of AlMu'awanah, Minggir, Sidoarjo on November 13, 2019.

Target

Target in this activity is all of the students of Class VII of the Islamic Junior High School of Al-Mu'awanah, Minggir, Sidoarjo.

\section{RESULTS AND DISCUSSION}

The activity starts at 08.15 until 09.00 WIB. The activity was carried out at the Islamic Junior High School of AlMu'awanah, Minggir, Sidoarjo. The 
counseling time is not according to plan because it has to adjust the student's schedule after doing the lesson. The students who attended were 26 students. The participants seemed enthusiastic in the process of delivering the material.

Equipment used during the counseling process are laptops, powerpoints, videos, leaflets, LCDs, posters. Using simple language and sentences, students of the Islamic Junior High School of AlMu'awanah, Minggir, Sidoarjo responded with enthusiasm. The teachers of the Islamic Junior High School of AlMu'awanah, Minggir, Sidoarjo want to work together in implementing this health promotion activity.

Every question asked by participants can be answered by all team members. $90 \%$ of participants can explain the meaning of menstruation condition; $90 \%$ of participants can mention the process of menstruation; $90 \%$ of participants can mention the causes of menstrual pain; $90 \%$ of participants can mention the first aid when menstrual pain; and $70 \%$ of participants can mention how to treat vital areas during menstruation.

\section{CONCLUSION}

Increasing youth knowledge in handling menstrual pain in students of the Islamic Junior High School of AlMu'awanah, Minggir, Sidoarjo was considered quite successful because $90 \%$ of participants can explain the meaning of menstruation condition; $90 \%$ of participants can mention the process of menstruation; $90 \%$ of participants can mention the causes of menstrual pain; $90 \%$ of participants can mention the first aid when menstrual pain; and $70 \%$ of participants can mention how to treat vital areas during menstruation.

\section{REFERENCES}

Andini. W. C. (2019). 4 Fase dalam Siklus Menstruasi yang harus Wanita Kenalli Tiap Bulan. Retrieved from https://hellosehat.com/hidupsehat/perawatan-kewanitaan/siklusfase-menstruasi/.

Andini, W. C. (2019). Penyebab Nyeri Haid yang Normal dan Tidak Normal. Retrieved from https://hellosehat.com/hidupsehat/perawatan-

kewanitaan/penyebab-nyeri-haidmenstruasi/.

Adrian, K. (2019). 9 Tip Menjaga Kesehatan Vagina saat Menstruasi. Retrieved from https://www.alodokter.com/9-tipsmenjaga-kesehatan-vagina-saatmenstruasi.

Ihsan. (2017). Pengertian Haid dan Kategorinya. Retrieved from http://simpulanilmu.blogspot.com/201 7/11/pengertian-haid-dankategorinya.html.

Putra, K. W. R., Ardian, M. I., Agustina, G. D., Amila, A., Prameswary, F. C., Aisy, R., \& Oktavia, V. (2019). IMPROVEMENT OF KNOWLEDGE OF STUDENTS OF MA'ARIF VOCATIONAL SCHOOL ON WOMEN'S REPRODUCTIVE HEALTH THROUGH HEALTH PROMOTION. Community Service Journal of Indonesia, 1(1), 1-3.

Marianti. (2018). Menstruasi. Retrieved from

https://www.alodokter.com/menstruasi.

Riesmiyatiningdyah, R., Wijianti, C. W., Nuriyah, S., Masela, L. G., Rahayu, D. S., Maulana, M. M., ... \& Rizqya, A. R. (2019). IMPROVED KNOWLEDGE OF YOUNG GIRL ABOUT 
MENARCHE IN THE RANGKAH KIDUL ELEMENTARY SCHOOL, RANGKAH KIDUL VILLAGE, SIDOARJO SUB-DISTRICT, SIDOARJO DISTRICT, EAST JAVA PROVINCE. Community Service Journal of Indonesia, 1(1), 14-17. 